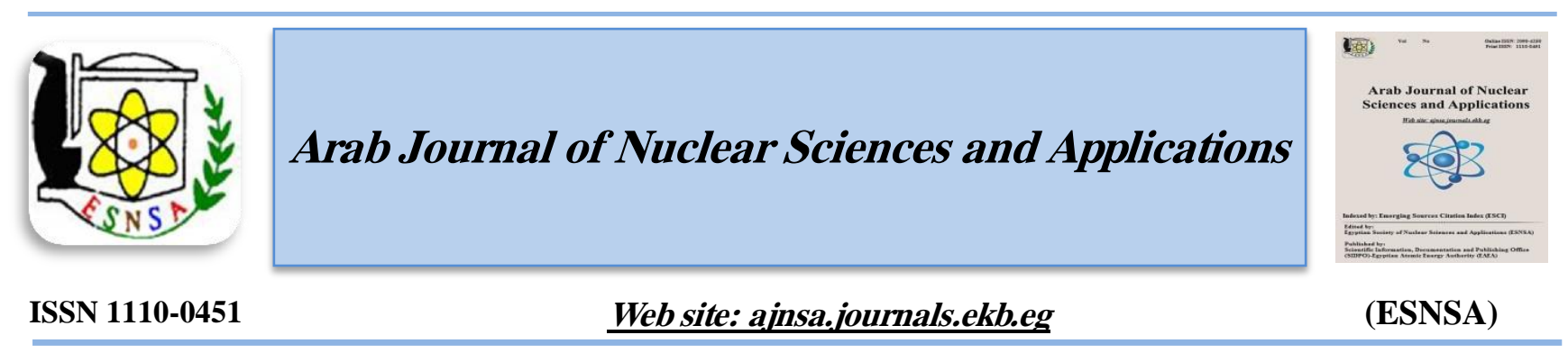

\title{
Effect of Dietary Olive Cake on Reproductive and Physiological Traits of Native Pregnant Ewes
}

\author{
A.A. El-Tarabany, M.M.M. Mostafa and A.K. Mohamed \\ Department of Biological Applications, Radioisotopes Applications Division, Nuclear Research Center, Atomic \\ Energy Authority, Cairo, Egypt
}

\begin{abstract}
Received $22^{\text {th }}$ Aug. 2017 The aim of the present study is to evaluate the effect of feeding olive cake (OC) on the reproductive and Accepted $12^{\text {st }}$ Oct. 2017 physiological traits of pregnant ewes. This study was conducted on 117 pregnant ewes, 11-12 months age, with an average weight of $41.5 \mathrm{~kg}$. The animals were divided into three equal groups; each group consisted of 39 ewes, given olives cake partitions representing 0,15 and $30 \%$ of the diet respectively. Feeding olive cake significantly $(p<0.05)$ increases the fertility rate and the proportion of twins, represented in an increment of ewes conceived twins (200-233\%). Addition of olive cake in diets at a rate of $15 \%$ resulted in significantly lower GOT, GPT, creatinine, urea, total lipid, cholesterol and estrogen levels. However, this led to increasing concentrations of progesterone hormone, in comparison with other groups. Thus, it can be recommended that using olive cake up to $15 \%$ in the diets of ewes has no negative effects on reproduction or physiological functions for improving twin's percentage.
\end{abstract}

Keywords: Olive cake, Pregnant ewes, Conceived twins, Physiological traits

\section{Introduction}

Olive by-products may be able to compete, in the feeding value, quality of product and cost, with conventional alternative feeds the cost of which may be subsidized. The relatively high prices of concentrates and its ingredients in Egypt are the major problem in animal production. At the same time, there is an increase in waste products from the olive cake industry and feasibility studies that have shown that there is a good intake for many livestock species without any harmful effect on health and blood parameters or carcass merits [1].

Nutritionally enjoined treatments marked influence on reproduction before any changes in live weight. This is particularly true in the case of short-term dietary changes and postulated an instant nutrient influence on the different reproductive traits [2]. Olive oil by-product is the preferable nutritional addition for pregnant ewes, due to its ideally balanced nutritionally valuable fats important for intrauterine fetal development, as well as voluntary fatty tissue development during early life [3]. Olive cake may help to improve fertility. This means that olive cake confirmed as the new fertility food and anticipating vision different olive cake diet plans emerging and suggesting ways to include olive cake in possessed as a supplement. Much reports are based on research carried out the style of diet could increase pregnancy rates by up to 40 percent. The most noticeable impact is around the time of mating on follicle development, embryo survival and twinning rate [4]. Callaghan et al. [5] reported that changes in grade of dietary intake are associated to changes in gonadotropin secretion, because of the functioning of the gonads, which also respond to dietary-induced blood-borne metabolic hormones and substrates. The number of lambs born per ewe is obviously an economically

Corresponding author:

DOI: $\underline{10.21608 / a j n s a .2018 .12788}$

(C) Scientific Information, Documentation and Publishing Office (SIDPO)-EAEA 
main trait in commercial sheep project; however profitability determined by the number of lambs per ewe. Therefore, a great deal of effort put toward the care of pregnant ewes and their lambs before, during and after birth.

Phenolic compounds from olives, as antioxidant, anti-inflammatory, antiviral, and anticancerogenic agents; these very important antioxidants prevent the oxidation of LDLs [6]. Such oxidation can cause damage to ordinary cells, nerve cells and arteries and lead to arteriosclerosis, coronary heart disease, or even cancer. In addition, olive cake consumption is beyond a reduction of the LDL cholesterol. Olive cake supply beta-carotene (provitamin A) and tocopherol (vitamin E) which prime buffers of acids produced in the gastrointestinal tract and those resulting from body metabolism [7]. Several trials have examined the effect of including olive by-products on animal performance; however, very few studies have addressed their effects on fertility. The present study has been conducted to assess the changes that occur in fertility and some physiological body functions in pregnant ewes fed olive cake (15 and $30 \%)$ in the diet.

\section{Materials and Methods}

Experimental procedures were conducted in accordance with the Atomic energy Authority Animal Ethics Committee guidelines (ANWD206).

\section{Animals and feeding}

The present work was carried out in the Sheep Farm, Project of Experimental Farms. The biochemical analysis was conducted in Tracer Bioclimatology Unit, Biological Applications Department, Nuclear Research Center, Atomic Energy Authority, Inshas, Egypt. A total of 117 ewes, aged 12-13 months with average body weight $41+3 \mathrm{~kg}$. Animals were housed indoor at day and night and kept under similar managerial and hygienic conditions. The proximate analysis of the ingredients used in ration and their chemical compositions are summarized in Table (1). The concentrate feed mixture in each group was offered individually twice daily at 8 am and $4 \mathrm{pm}$. The animals were fed on their diets from weaning to parturition. Drinking water also was provided adlib.

\section{Experimental design}

Animals were divided into three equal groups, 39 ewes each, comprised first parity only. The first group was considered as control, with $0 \%$ olive cake. The second and third groups were fed olive cake at a ratio of 15 and $30 \%$ of the diet respectively. The olive cake used in the current study was collected after extracting the oil and purchasing from New El-Salheya olive mill factory-Sharkia Governorate, Egypt. This factory extracting the olive oil by wet crushing for whole fruits with and extracting the oil by centrifugation and the residual after extracting was sun dried for about 15 days.

\section{Blood sampling and biochemical analysis}

Blood samples were collected in vacuum tubes at the mating and monthly during the whole pregnancy period. Samples without anticoagulant to obtain serum by centrifugation at the rate of $3000 \mathrm{rpm}$ for 20 minutes and stored at $-20^{\circ} \mathrm{C}$ until analysis. Serum used to determine total protein, albumin, total lipid, cholesterol, HDL, LDL, kidney function (urea and creatinine), liver function (glutamic oxalocetic transaminase, GOT and glutamic pyruvic transaminase, GPT) and estradiol $_{17 \beta}$ and progesterone hormones. All the above-mentioned blood parameters were determined using commercial kits manufactured by Bio-Diagnostic Company, Egypt. Estradiol ${ }_{17 \beta}$ and progesterone hormones levels estimated by RIA using coated tubes kit; DSL, Inc. Webster, Texas, USA and counting using computerize Gamma Counter. The tracer in the hormones labeled with Iodine-125 ( $\left.\mathrm{I}^{125}\right)$.

\section{Reproductive traits}

Gestation length, litter size, litter weight and birth weight were recorded. Reproductive indices were calculated for each animal in three groups. Fertility $\%$ : number of goats that kidded/number of goats joined to the bucks $x$ 100. Prolificacy rate: number of kids born/number of goats that kidded. Fecundity \%: number of kids born/number of goats joined to the buck's x 100. Mortality and survivability rates were calculated.

Statistical analysis

All statistical procedures performed using SAS statistical system Package V9.1 SAS, [9]. Chisquare test used to evaluate the association between ration groups and proportion dichotomous variables (lambing traits and pregnancy rate). 
Table (1): Ingredients and chemical composition of experimental diets percentage groups

\begin{tabular}{|c|c|c|c|}
\hline \multirow{2}{*}{ Ingredients } & \multicolumn{3}{|c|}{ Experimental diets groups } \\
\hline & Control & $\begin{array}{l}{ }^{3} \mathrm{OC} \\
(15 \%)\end{array}$ & $\begin{array}{l}O C \\
(30 \%)\end{array}$ \\
\hline Crushed yellow corn & 22.5 & 14 & 7 \\
\hline Dried sugar beet pulp & 23 & 14.5 & 6.5 \\
\hline Wheat bran & 25 & 25 & 25 \\
\hline $\begin{array}{l}\text { Undecorated cotton } \\
\text { seed cake }\end{array}$ & 27 & 29 & 29 \\
\hline Olive oil by-product & 0 & 15 & 30 \\
\hline Sodium chloride & 1 & 1 & 1 \\
\hline Di-calcium phosphate & 1 & 1 & 1 \\
\hline Sodium bicarbonate & 0.1 & 0.1 & 0.1 \\
\hline${ }^{l}$ Vit. $A D_{3} E$ & 0.1 & 0.1 & 0.1 \\
\hline${ }^{2}$ Mineral mixture & 0.3 & 0.3 & 0.3 \\
\hline \multicolumn{4}{|c|}{ Chemical composition(\%) on DM basis } \\
\hline$D M$ & 90.61 & 90.87 & 91.09 \\
\hline$O M$ & 93.23 & 92.99 & 92.69 \\
\hline$C P$ & 16.98 & 16.72 & 16.70 \\
\hline$C F$ & 12.93 & 21.89 & 24.48 \\
\hline$E E$ & 3.86 & 4.97 & 6.21 \\
\hline$N F E$ & 59.46 & 49.41 & 45.30 \\
\hline Ash & 6.7 & 7.01 & 7.31 \\
\hline${ }^{4} G E(M J / k g D M)$ & 18.41 & 18.75 & 19.02 \\
\hline \multicolumn{4}{|c|}{ 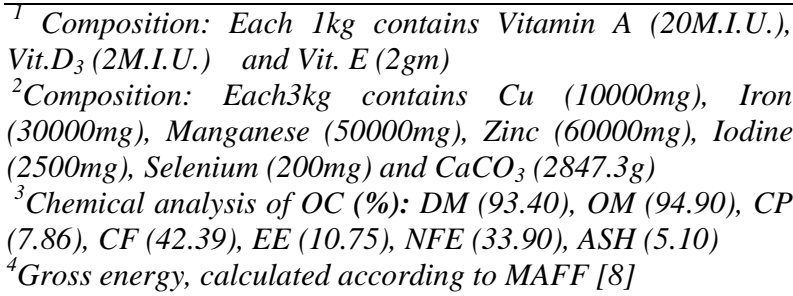 } \\
\hline
\end{tabular}

Significant results followed by multiple Z-tests to compare corresponding proportions. $P$-value for all pairwise comparisons adjusted using the Bonferroni correction. GLM procedure of SAS used to analyze the repeated measure variables. The model for statistical analyses included the fixed effects of experimental ration and the random effect of replicates. The statistical model was as follows: $Y_{i j}=\mu+T_{i}+e_{i j}$ where $Y_{i j}=$ the observation, $\mu=$ overall mean, $T_{i}=$ the fixed effect of treatments $(1=$ control, $2=$ OC $15 \%, 3=$ OC $30 \%), \mathrm{e}_{\mathrm{ij}}=$ the random error. The comparison of means carried out with Duncan's multiple range tests, after verifying normality using KolmogorovSmirnov test.

\section{Results and Discussion}

Effect of dietary olive cake on Reproductive performance traits
Reproductive traits of native ewes supplemented with dietary olive cake are summarized in Table (2). It was clear that supplementing olive cake has a significant effect on most of studied traits.

The lambing rate increased with supplementing dietary olive cake to pregnant ewes. The higher rate of kidding was recorded in the second and third groups (78.48 and $84.61 \%$, respectively) than in control group $(69.23 \%)$. The observed beneficial effect of vitamin $\mathrm{A}$ in olive cake probably mediated through improvement in fetal nutritional status, enhancement of fetal immunity and decreased risk of infections, which together would decrease risks of intrauterine growth retardation, fetal loss, preterm birth, and low birth weight [10]. Potential mechanism of action of the vitamin $\mathrm{A}$ is through improvement of pregnant female hematological status: low hemoglobin concentrations are associated with higher risks of miscarriages, preterm birth, and low birth weight [11].

Lambs were born single approximately equal number in three groups. While, twins increase in dietary olive cake pregnant ewes by 200-233\%. Lambing percentage is the biggest contributor to get higher profits from sheep farms. The decline was in twins -bearing ewes compensated by an increase in single -bearing ewes. The immense importance of vitamin $\mathrm{E}$ in optimizing fecundity rates and litter size demonstrated by the fact that maximal early growth and general wellbeing in weanling animals depend amongst other factors, on correct vitamin E supplementation to pre and post coitum [12]. Consequently, when animal's diets fortified with vitamin $\mathrm{E}$, an increased litter size at birth has generally been demonstrated [13]. Male lambs were higher kidding rate than females by $40-100 \%$ in groups fed on olive cake in comparison with control group.

Higher fertility rate has been recorded in ewes feeding olive cake than control ewes by 33.23 and $37.03 \%$, respectively. Prolificacy was higher in ewes feeding olive cake than in control ewes by 2.52 and $2.25 \%$, respectively. Prolificacy rate average was 1.127 , involving $80.53 \%$ of single and $19.46 \%$ twins. Fecundity percentage was higher in ewes feeding olive cake than control ewes by 36.66 and $40.0 \%$, respectively. These results were similar to those obtained by Fonseca [14]; the 
overall fertility rate observed in this study $(82.05 \%)$ was based on the number of goats kidding at term. Failures due to embryo losses and abortions were not considered and this could explain differences in the fertility ranges of 69$94 \%$, reported by others from enquires to the farmers, but without any experimental support.

It appears that, the reproductive response to improved planes of nutrition dependent on prolificacy level of the breed, the higher of ovulation rate and litter size [15]. As a result, the use of concentrates as an expensive resort to supplement low prolific animals of the local breeds prior to mating may not lead to improvement in their reproductive traits[16], and the authors suggested that alternative feed resources need to be envisaged as a more sustainable strategy in low input systems. Indeed, the high cost of concentrates associated to limited availability hamper their wide scale use, especially by small farmers [17].

\section{Litter traits}

Litter traits of native ewes supplemented with olive cake are listed in Table (3). Groups supplemented with olive cake had improved litter traits compared to control group.

Table (2): Reproductive traits of native ewes supplemented with dietary olive cake

\begin{tabular}{|c|c|c|c|c|}
\hline \multirow{2}{*}{ Items } & \multicolumn{3}{|c|}{ Dietary groups } & \multirow{2}{*}{$P$ values } \\
\hline & Control & OC $15(\%)$ & OC 30 (\%) & \\
\hline No. of ewes & 39 & 39 & 39 & \\
\hline \multirow[t]{2}{*}{ Lambing rate $(\%)$} & $69.23^{\mathrm{b}}$ & $79.48^{\mathrm{b}}$ & $84.61^{\mathrm{a}}$ & 0.01 \\
\hline & \multicolumn{2}{|c|}{ Patterns of litter size (\%) } & & \\
\hline $\begin{array}{l}\text { Single } \\
\text { Twins }\end{array}$ & $\begin{array}{l}88.9^{\mathrm{a}} \\
11.1^{\mathrm{b}}\end{array}$ & $\begin{array}{l}67.8^{\mathrm{b}} \\
32.2^{\mathrm{a}}\end{array}$ & $\begin{array}{l}72.8^{\mathrm{ab}} \\
27.2^{\mathrm{ab}}\end{array}$ & $\begin{array}{c}0.02 \\
0.001\end{array}$ \\
\hline $\begin{array}{l}\text { Male } \\
\text { Female }\end{array}$ & $\begin{array}{l}50^{\mathrm{b}} \\
50^{\mathrm{a}}\end{array}$ & $\begin{array}{c}\operatorname{tio}(\%) \\
51.2^{\mathrm{b}} \\
48.8^{\mathrm{a}}\end{array}$ & $\begin{array}{l}73.2^{\mathrm{a}} \\
26.8^{\mathrm{b}}\end{array}$ & $\begin{array}{l}0.04 \\
0.01\end{array}$ \\
\hline $\begin{array}{l}\text { Fertility }(\%) \\
\text { Prolificacy rate } \\
\text { Fecundity }(\%)\end{array}$ & $\begin{array}{l}69.23^{\mathrm{b}} \\
1.11^{\mathrm{b}} \\
76.92^{\mathrm{b}}\end{array}$ & $\begin{array}{l}\text { ve efficiency } \\
92.30^{\mathrm{a}} \\
1.138^{\mathrm{a}} \\
105.12^{\mathrm{a}}\end{array}$ & $\begin{array}{l}94.87^{\mathrm{a}} \\
1.135^{\mathrm{a}} \\
107.69^{\mathrm{a}}\end{array}$ & $\begin{array}{l}0.05 \\
0.04 \\
0.01\end{array}$ \\
\hline
\end{tabular}

Values with different superscripts in each row are significantly different at $(\mathrm{p}<0.05)$

Table (3): Litter traits of native ewes supplemented with dietary olive cake

\begin{tabular}{lllll}
\hline \multirow{2}{*}{ Items } & \multicolumn{2}{l}{ Dietary groups } & \\
\cline { 2 - 4 } & Control & OC 15 $(\%)$ & OC 30 $(\%)$ & $p$-value \\
\hline Gestation length (day) & $152.3^{\mathrm{a}} \pm 5.62$ & $146.25^{\mathrm{b}} \pm 5.10$ & $147.74^{\mathrm{b}} \pm 4.92$ & 0.05 \\
Litter size(No) & $1.11^{\mathrm{b}} \pm 0.11$ & $1.41^{\mathrm{a}} \pm 0.14$ & $1.38^{\mathrm{a}} \pm 0.14$ & 0.029 \\
Litter weight (kg) & $7.55^{\mathrm{b}} \pm 0.47$ & $8.91^{\mathrm{a}} \pm 1.46$ & $8.30^{\mathrm{a}} \pm 1.20$ & 0.003 \\
Lamb weight (kg) & $4.52 \pm 0.32$ & $4.26 \pm .34$ & $4.19 \pm 0.33$ & 0.230 \\
Stillbirth (\%) & 0.00 & 0.00 & 4.7 & 0.244 \\
\hline
\end{tabular}

Stillbirth: defined as death of a lamb that occurs just prior to, during, or within $48 \mathrm{~h}$ from parturition.

$a, b$ values in the same row having different superscripts per each item differ significantly. 
Olive cake in the diet of pregnant ewes affected significantly $(\mathrm{p}<0.05$ or 0.01$)$ on gestation length, litter size and litter weight. Olive cake in the diet decreased gestation length by -3.97 and $2.99 \%$, respectively. In addition, litter size and litter weight at birth improved significantly in ewes fed olive cake as compared to ewes fed control diet. The improvement percentage of litter size by 27.02 and $24.32 \%$, respectively, while of litter weight by 18.02 and $9.93 \%$, respectively. At the same time, the percentage of mortality at birth recorded zero in control and $15 \%$ as compare with $30 \%$ olive cake groups.

Dietary olive cake contain of vitamin $\mathrm{E}$ required during gestation and lactation to prevent reproductive failures [18]. In the animal body, vitamin $\mathrm{E}$ is present primarily as alpha tocopherol. Vitamin $\mathrm{E}$ is essential for growth and mostly, during critical periods of embryonic development to enhance embryo survival [13]; it also acts as an intracellular antioxidant [18]. Vitamin $\mathrm{E}$ in olive cake affect growth development and health status of cattle, [19]; and several other animal species, [20]; resulting in foetal death and resorption, [21]; with a concomitant reduction in profitability of animals. Consequently, increasing dietary vitamin $E$ intake during gestation resulted in an increase in litter size and a reduction of pre-weaning mortality [22]. Earlier reports concluded that the antioxidant properties as well as an immuno-modulating effect may be the reasons, and may be important for the general wellbeing of weanling animals [12]. Interestingly, olive cake contain of vitamin $\mathrm{E}$, has important immediate during early development and short-term effects on growth, body composition and body functions [13].

\section{Physiological parameters}

Liver and kidney function, lipid profiles and hormones levels of different groups are listed in Table (4).

Olive cake in the diet of pregnant ewes affected significant $(\mathrm{p}<0.05$ or 0.01$)$ on serum total protein, albumin and globulin concentrations. The groups fed 15 and 30\% olive cake had lower total protein, albumin and globulin than control group. This result suggests that, the effect of olive cake on liver synthesis of total proteins, which used as markers for liver damage; a rise in these proteins is associated with the development of a nonalcoholic liver pathology, such as fatty liver, linked to metabolic syndrome. These results indicate a return to normal globulin levels because of olive cake consumption. This could have induced a reversion to the damage caused to the liver parenchyma through statuses, given that in this pathology blood globulin levels remain high [23].

Table (4): Liver and kidney function, lipid profiles and hormones level as affected by dietary olive cake in native ewes

\begin{tabular}{|c|c|c|c|c|}
\hline \multirow{2}{*}{ Items } & \multicolumn{3}{|c|}{ Dietary groups } & \multirow{2}{*}{$p$-value } \\
\hline & Control & $15(\%) \mathrm{OC}$ & $30(\%) \mathrm{OC}$ & \\
\hline Total proteins $(\mathrm{g} / \mathrm{dl})$ & $7.23^{\mathrm{a}} \pm 0.05$ & $6.49^{\mathrm{b}} \pm 0.12$ & $6.03^{\mathrm{b}} \pm 0.03$ & 0.01 \\
\hline Albumin $(\mathrm{g} / \mathrm{dl})$ & $3.85^{\mathrm{a}} \pm 0.03$ & $3.38^{\mathrm{b}} \pm 0.13$ & $3.52^{\mathrm{b}} \pm 0.06$ & 0.02 \\
\hline Globulin (g/dl) & $3.38^{\mathrm{a}} \pm 0.10$ & $3.11^{\mathrm{b}} \pm 0.12$ & $2.51^{\mathrm{b}} \pm 0.09$ & 0.01 \\
\hline GOT (u/ml) & $35.86^{\mathrm{a}} \pm .024$ & $31.26^{\mathrm{b}} \pm 0.23$ & $31.53^{\mathrm{b}} \pm 0.37$ & 0.01 \\
\hline GPT (u/ml) & $13.12^{\mathrm{a}} \pm 0.08$ & $11.10^{\mathrm{b}} \pm 0.02$ & $10.56^{\mathrm{b}} \pm 0.05$ & 0.01 \\
\hline Creatinine (mg/dl) & $1.35^{\mathrm{a}} \pm 0.05$ & $1.29^{\mathrm{b}} \pm 0.04$ & $1.31^{\mathrm{b}} \pm 0.05$ & 0.05 \\
\hline Urea (mg/dl) & $28.93^{\mathrm{a}} \pm .017$ & $27.91^{\mathrm{b}} \pm 0.18$ & $28.06^{\mathrm{b}} \pm 0.08$ & 0.01 \\
\hline Total lipid & $4.02^{\mathrm{b}} \pm 0.01$ & $3.73^{\mathrm{c}} \pm 0.01$ & $4.20^{\mathrm{a}} \pm 0.05$ & 0.01 \\
\hline Cholesterol (mg/dl) & $102.0^{\mathrm{a}} \pm 1.35$ & $91.30^{\mathrm{b}} \pm 1.66$ & $86.60^{\mathrm{b}} \pm 1.18$ & 0.01 \\
\hline $\mathrm{HDL}(\mathrm{mg} / \mathrm{dl})$ & $63.73^{\mathrm{c}} \pm 4.33$ & $68.56^{\mathrm{b}} \pm 3.38$ & $74.33^{\mathrm{a}} \pm 3.67$ & 0.001 \\
\hline $\mathrm{LDL}(\mathrm{mg} / \mathrm{dl})$ & $83.53^{\mathrm{a}} \pm 2.31$ & $77.80^{c} \pm 3.20$ & $80.79^{b} \pm 3.69$ & 0.01 \\
\hline Estradiol $_{17 \beta}(\mathrm{pg} / \mathrm{ml})$ at mating & $0.34^{\mathrm{a}} \pm 0.05$ & $0.18^{\mathrm{b}} \pm 0.02$ & $0.19^{\mathrm{b}} \pm 0.03$ & 0.05 \\
\hline $\begin{array}{l}\text { Progesterone }(\mathrm{ng} / \mathrm{ml}) \text { during } \\
\text { pregnancy }\end{array}$ & $7.85^{\mathrm{c}} \pm 0.20$ & $10.17^{\mathrm{ab}} \pm 0.59$ & $11.99^{\mathrm{a}} \pm 0.23$ & 0.01 \\
\hline
\end{tabular}

a, $b$ and $c$ means in the same row having different superscripts per each item differ significantly $(P<0.05$ to 0.001$)$ 
The activity of GOT and GPT was significantly lower $(p<0.01)$ in the group fed 15 and $30 \%$ olive cake than in the other group. The effect of administering a diet rich in carbohydrate, known to contribute to metabolic syndrome through oxidative stress, among other effects and in consequence to hepatic metabolic changes [24]. Olive cake was recognized with a high percentage of unsaturated fatty acids and a low percentage of saturated [25], different transcriptomic responses between diets based on different long-chain polyunsaturated fatty acids have been observed. Furthermore, stereochemistry influences differential responses as seen with linoleic acid isomers [26]. In addition, the role of vitamin $\mathrm{E}$ a powerful antioxidant; was decreased oxidative stress and fat deposition. Likewise, the benefits of vitamin E, included reduced triglyceride accumulation in the liver, decreased level of lipid peroxides, improved liver damage markers and inhibited liver fibrosis [27].

The concentrations of creatinine and urea-N were significantly $(\mathrm{P}<0.05$ or 0.01$)$ lower in the group fed 15 and $30 \%$ olive cake than in the control group. Literatures have shown olive by-product with nephroprotective properties to mediate their protection via antioxidant and/or free radical scavenging activities due to the high concentration of biophenols they contain. In this aspect, Tavafi et al.[28] found that olive leaf extract protects from gentamicin-induced nephrotoxicity possibly by inhibition of lipid peroxidation, enhancing renal glutathione content and antioxidant enzymes activity. In addition, Visioli et al. [29], found that olive phenolics increase glutathione levels in healthy volunteers. The effective role of the extracts may partially explain by hypotensive effects of olive by- product extract that make kidney work normally [30]. Again, the histological findings of almost normal renal histological architecture corroborate the decreased levels of urea and creatinine confirmed protection effects by the extract within the stipulated time interval, especially at the maximum oral dose the extract [31].

Olive cake in the diet affected significantly on total lipids, total cholesterol, HDL and LDL. The concentration of total lipids was higher and total cholesterol was lower in the group fed $30 \%$ olive cake than in the two groups, control and $15 \%$ olive cake. HDL concentration was higher in ewes fed olive cake than control group, while LDL showed the opposite trend. Mensink and Katan[32] concluded that olive cake served a focal role in providing a source of mono- and poly- unsaturated fats. These contributions to a healthy diet can positive impacts on cholesterol levels by helping to maintain a balance between HDL and LDL cholesterol. Studies confirmed that, diets high in saturated fats raise LDL, while diets high in monounsaturated and poly-unsaturated fats decrease LDL levels. Visioli and Galli [33] carried out additional studies revealed that, high monounsaturated content, natural olive cake contains non-fat components such as certain phenolic compounds that a wide range of health benefits including positive impacts on cholesterol levels and LDL oxidation. Mustafa [1] reported that cholesterol concentration was significantly decreased with high level addition of olive cake and this may due to that olive cake contains high level of omega-3 fatty acids which responsible for decreasing level of cholesterol concentration.

Olive cake in the diet decreased significantly the level of $\mathrm{E}_{2}$ at mating and increased $\mathrm{P}_{4}$ levels during pregnancy compare with control ewes. Fertility hormones regulate the reproductive cycle in females and used test for infertility and early or delayed puberty. These are associated with ovulation, ovarian syndrome and premature ovarian failure. Fat in olive cake has been involved in the production and regulation of steroid hormones, which are hydrophobic molecules made from cholesterol in the smooth endoplasmic reticulum, a compartment within a cell in which lipids, hormones, and proteins. Steroid hormones are essential in regulating sexuality, reproduction, development of the sex organs and regulating the water balance in the body [34]. In addition, Steroid hormones can freely flow in and out of cells, and they modify the transcription process, which is the first step in protein synthesis [35]. Harrison et al. [36] suggested that vitamin E act at the cellular level by regulating the generation of free radicals in the ovaries. Staats et al. [37] showed that vitamin $\mathrm{E}$ protected steroidogenic enzymes from oxidative degeneration; however, Rapoport et al.

Corresponding author:

DOI: $\underline{10.21608 / a j n s a .2018 .12788}$

(C) Scientific Information, Documentation and Publishing Office (SIDPO)-EAEA 
[38] found that the concentration of a-tocopherol in ovarian tissue related to the animals' consumption of vitamin $\mathrm{E}$ during the period of maximal progesterone production. Egba et al. [39] suggested that vitamin $\mathrm{E}$ promoted the release of follicle stimulating hormone (FSH), adrenocorticotrophic hormone (ACTH) and luteinising hormone $(\mathrm{LH})$. There may also be a role for vitamin $\mathrm{E}$ in the protection of the pathway from arachidonic acid to prostaglandins, which are closely involved in the regulation of the reproductive system.

\section{Conclusion}

The results showed that feeding olive cake significantly increase the fertility $\%$ and the proportion of twins, thus increase the number of ewes conceived twins by up to 200-233\%. Therefore, olive cake in a concentrate-based diet for pregnant ewes has recommended as a natural strategy to improve the physiological body functions and reproductive traits without compromising oxidative stability.

\section{References}

1- M.M. Mustafa; Isotope and Radiation Research; 40, 507 (2011).

2- J.F. Smith and R.D. Stewart; "Effects of nutrition on the ovulation rate of ewes". In: Reproductive physiology of Merino sheep. Concepts and Consequences, Oldham, C.M., Martin, G.B. and Purvis, I.W. (eds). School of Agriculture (Animal Science), the University of Western Australia. Nedlands, pp. 85-101. (1990).

3- J.F. Aguilera, M.A. García and E. Molina; Animal Production 55, 219 (1992).

4- C. Viñoles; "Effect of nutrition on follicle development and ovulation rate in the ewe". Doctoral thesis. ISSN; 1401-1625. (2003).

5- D.O. Callaghan, H. Yaakub, P. Hyttel, L.J. Spicer and M.P. Boland; Journal of Reproduction and Fertility, 118, 303 (2000).

6- G. Luciano, M. Pauselli, M. Servili, E. Mourvaki, A. Serra, F.J. Monahan, M. Lanza, A. Priolo, A. Zinnai and M. Mele; J. Meat Sci. Mar; 93(3), 703 (2013).

7- M. Savarese, D. Marco and E. Sacchi E; Food Chemistry; 105, 761 (2007).

8- MAFF; "Ministry of Agriculture, Fisheries and Food Department of Agriculture and Fisheries for Scotland", Department of Agriculture for northern Ireland 1975 Energy Allowances and Feeding Systems for ruminants Technical Bulletin No 33 Her Majesty's Stationery Office London (1975).

9- SAS; STAT User's Guide. (Version 6,4 Th Ed.). SAS Inst. Inc, Cary, NC (2002).
10- Cabiddu, M. Canu, M. Decandia, G. Molle and R. Pompel; Zaragoza: CIHEAM, Options Mediterranean's: Série A. Séminaires Méditerranéens; 59, 197 (2004).

11- Raúl Vera1, Claudio Aguilar, Rodrigo Lira, Paula Toro, Luis Barrales, Iván Peña1, Fernando Squella, Patricio Pérez, Javiera Quenaya, Hanja Yutronic, and Ignacio Briones; J. Agricultural Research; 69(4), 548 (2009).

12- J.L. Capper, R.G. Wilkinson, E. Kasapidou, S.E. Pattinson, A.M. MacKenzie and L.A. Sinclair; British Journal of Nutrition; 93, 549 (2005).

13- R.L. Stuart and E. Kane; Feedstuffs; 76, 11 (2004).

14- M. Fonseca; "Situation of the goat breeding in Portugal". II Jornadas Nacional de Caprinicultura, Sociedade Portugese de. Ovinotecnia e Caprinotecnia, Castelo Branco (Portugal), 7-9 April. pp. 87-117 (1988).

15- N. Lassoued, M. Rekik, M. Mahouachi and M. Ben Hamouda; Small Ruminant Research; 52, 117 (2004).

16- G.B. Martin, G.T.B. Milton, R.H. Davidson, G.E. Banchero Hunzicker, D.R. Lindsay and D. Blache; Anim. Repro. Sci.; 83, 231 (2004).

17- H. Ben Salem and A. Nefzaoui; Small Ruminant Research; 49, 275 (2003).

18- D.O. Umesiobi; The Philippine Agricultural Scientist; 91, 379 (2008).

19- K.P. Waller, C.H. Sandgren, U. Emanuelson and S.K. Jensen; Journal of Dairy Science; 90, 3640 (2007).

20- L.R. McDowell; Pakistan Journal of Nutrition; 1, 8 (2002).

21- T. Sivertsen, A. VieE, Bernhoft and B. Baustad; Acta Veterinaria Scandinavia; 49(1), 88 (2007).

22- S. Fragou, K. Balaskas, A. Fegeros and I. Politis; Journal of Veterinary Medicine. A, Physiology, Pathology, Clinical Medicine; 53, 327 (2006).

23- J.M. Clark and A.M. Diehl; Journal of the American Medical Association, 289, 3000 (2003).

24- (24) Z.H. Yang, H. Miyahara, J. Takeo and M. Katayama; Diabetology \& Metabolic Syndrome; 4, 32 (2012)

25- M. Wong, C. Requejo-Jacman and A. Woolf; American Oil Chemists Society (2010).

26- Octavio Carvajal-Zarrabal, Cirilo NolascoHipolito, Ma. Guadalupe AguilarUscanga, Guadalupe Melo Santiesteban, Patricia M. Hayward-Jones, and Dulce Ma. Barradas-Dermitz; BioMed. Research International; 1 (8), 69 (2014).

27- A.Z. Karakilcik, M. Zerin, O. Arslan, Y. Nazligul and H. Vural; Veterinary and Human Toxicology; 46, 190 (2004).

28- M. Tavafi, H. Ahmadvand and P. Toolabi ; Iranian Journal of Kidney Disease; 6, 25 (2012).

29- F. Visioli, R. Wolfram, D. Richard, M. Imran, B. Abdulla and R. Crea; Journal of Agriculture Food Chemistry; 57, 1793 (2009). 
30- A. Nekooeian, G. Dehghani, H. Mostafavi and A. Khalili; Iran Cardiovascular Research Journal, 5, 1 (2011).

31- A.E. Bawazir; World Journal of Neuroscience; 1, 31 (2011).

32- R.P. Mensink and M.B. Katan; Arteriosclerosis Thromb.; 12, 911 (1992).

33- F. Visioli and C. Galli; Crit Rev Food Science Nutrition; 42, 209 (2002).

34- D.T. Baird, V.H.T. James, M. Serio and G. Giusti; "Ovarian steroid secretion and metabolism in women". In: the endocrine function of the human ovary. Academic Press, New York; pp: 125-133 (1976).

35- N.A. Campbell; Biology, $4^{\text {th }}$ edition. San Francisco: Benjamin/Cummings (2000).
36- J.H. Harrison, D.D. Hancock and H.R. Conrad; Journal of Dairy Science; 67, 123 (1984).

37- D.A. Staats, D.P. Lohr and H.D. Colby; Endocrinology; 123, 975 (1988).

38- R. Rapoport, D. Sklan, D. Wolfenson, A. ShahamAlbalancy and I. Hanukoglu; Biochimica et Biophysica Acta; 1380, 133 (1998).

39- S.I. Egba, I.D. Udom and C.O. Oknkwo; Global Journal of Biotechnology and Biochemistry; 9(1), 24 (2014). 